\title{
Research on the Reaction of Soybean Cultivars to Diseases Attack in 2013, in the County of Brăila
}

\author{
Alexandru Gheorghe BĂLAȘU ${ }^{1}$, Cristinel Relu ZALA $\breve{1}^{1^{*}}$ and Stelica CRISTEA ${ }^{1}$ \\ ${ }^{1}$ Department of Plant Science. University of Agronomic Sciences and Veterinary Medicine, Bucharest \\ 59 Marasti Blvd District 1, 011464, Bucharest, Romania. \\ * corresponding author: cristizala@yahoo.com
}

Bulletin USAMV series Agriculture 72(1)/2015

Print ISSN 1843-5246; Electronic ISSN 1843-5386

DOI 10.15835/buasvmcn-agr: 11175

\begin{abstract}
Bacterial burning is a widespread disease in soybeans, which occurs most frequently under cold and wet climate. Soybean mosaic potyvirus is spread everywhere in the world wide as the most damaging viral phytopathogens soybeans. Fusarium species can infect plants at any stage of soybean development. The objective of this research was to estimate the degree of attack of Soybean mosaic potyvirus, bacterial burn and Fusarium species in soybeans. The goal was to have the necessary information in making decisions applying for phytosanitary treatments. Three cultivars were tested: PR92M22, PR92B63, PR91M10, and observations were made under natural contamination on the 15th of July and August 30, 2013. In order to know the health of the experimental lot phytosanitary control were carried in R1 and R4 growth stages, specifying the frequency and intensity of the detected pathogens attack. The research was conducted in the experimental fields without irrigation, in Unirea city and in the Great Island, county of Brăila. From this paper it can be concluded that one of the main limiting factors in soybean crop is found in a very large extent of the phytosanitary nature, like the attack of the Soybean mosaic potyvirus, bacteria Pseudomonas savastanoi pv. glycinea and Fusarium species. The degree of infection varied from one cultivar to another. The study was developed during the proces of doctoral studies.
\end{abstract}

Keywords: attack degree, bacterial burning, cultivars, soybean, soybean mosaic potyvirus.

\section{INTRODUCTION}

Soybeans were introduced and expanded in culture in Romania in 1911 (Dencescu and Popa, 1973). Soybean mosaic potyvirus is spread everywhere in the world wide as the most damaging viral phytopathogens soybeans. Soybean mosaic causes stunting of plants and crinkled and mottling of leaves. Most commercial soybean varieties are susceptible to Soybean mosaic potyvirus. The resistance or susceptibility of most commercial soybean cultivars to Soybean mosaic potyvirus is not known (Wang et al., 2006). Infection of soybean plants with Soybean mosaic potyvirus, which is transmitted by aphids and through seed, can cause significant reductions in seed production and quality (Domier et al., 2011). The phytopathogenic pseudomonads have evolved a spectrum of physiological features that permit them to parasitize most major plant groups. Consequently, they are of substantial economic importance worldwide (Gross and Cody, 1985). Bacterial burning is a widespread disease in soybeans, which occurs most frequently under cold and wet climate. Widely cultivated soybean is susceptible to diseases, the most common being the bacterial ones (Jagtap and Dey, 2012). Fusarium species can infect plants at any stage of soybean development but infection is particularly favored when plants are weakened. Fusarium species are widespread soilborne organisms capable of surviving for long periods of time as chlamydospores and as mycelium in plant residues and in soil. The Fusarium wilt and necrosis of root 
and lower of soybean is an important disease in many countries. It can cause great damage, as it may reduce the average yield of soybean by up to 59\% (Sinclair and Backman, 1989). Soybean mosaic potyvirus, Pseudomonas savastanoi pv. glycinea (Janse 1982) Gardan et al. 1992, and Fusarium species are biotic factors, which plays a limiting role soybeans under favorable conditions, the attack decreasing the production. Under certain environmental conditions, serious economic losses can occur. The research was conducted in the experimental fields without irrigation, in Unirea city and in the great Island, county of Brăila. The results of this paper are part of doctoral thesis. The objective of this research was to estimate the degree of attack of soybean mosaic, bacterial burning, and Fusarium disease in soybeans.

\section{MATERIALS AND METHODS}

Three cultivars were tested: PR91M10, PR92B63, and PR92M22. Visual observation is the fastest method to identify a disease based on signs and symptoms shown by infected soybean plants. Scouting for pathogens attack has a particular importance in soybean to establishing the need for chemical treatments during the vegetation season. The attack value is represented by frequency (F\%), intensity (I\%) and attack degree (AD\%). Frequency is the percentage of plant attacked out of 100 examined soybean plants. Intensity indicates the degree to which the soybean plant is attacked under examination. Intensity was noted directly in percentage. The attack degree present severity of pathogens in the crop and was calculated using the frequency (disease incidence) and intensity (severity). Attack degree was calculated using the formula:

$$
\text { A.D. }=\frac{F \% \times I \%}{100} \text {. }
$$

The experimental block surface was placed in four repetitions. Observations were made under natural contamination on the 15th of July, at growth stage R1 and August 30, 2013, at growth stage R4 (Fehr et al., 1971).

\section{RESULTS AND DISCUSSION}

Infected plants with Soybean mosaic potyvirus (SMV) and Pseudomonas savastanoi pv. glycinea
(PSG) manifested only lesions on the leaves. Common leaf symptoms of Soybean mosaic potyvirus are a mosaic of light and dark green areas, and leaf curl (fig. 1.). The lesions of bacterial burning usually begin as small, angular and yellow. Lesions progress in color from yellow to light brown and eventually to a dark reddish brown. Older lesions have a dark center surrounded by a water-soaked margin and a yellow halo. Angular lesions may enlarge and merge, producing large, irregular dead areas in the leaf. With wind and rain these large dead areas drop out or tear away, giving the leaf a ragged appearance (fig. 2.). Fusarium root (fig. 3.) and wilt starts out looking like vein clearing on the younger leaves and drooping of the older lower leaves, followed by stunting of the

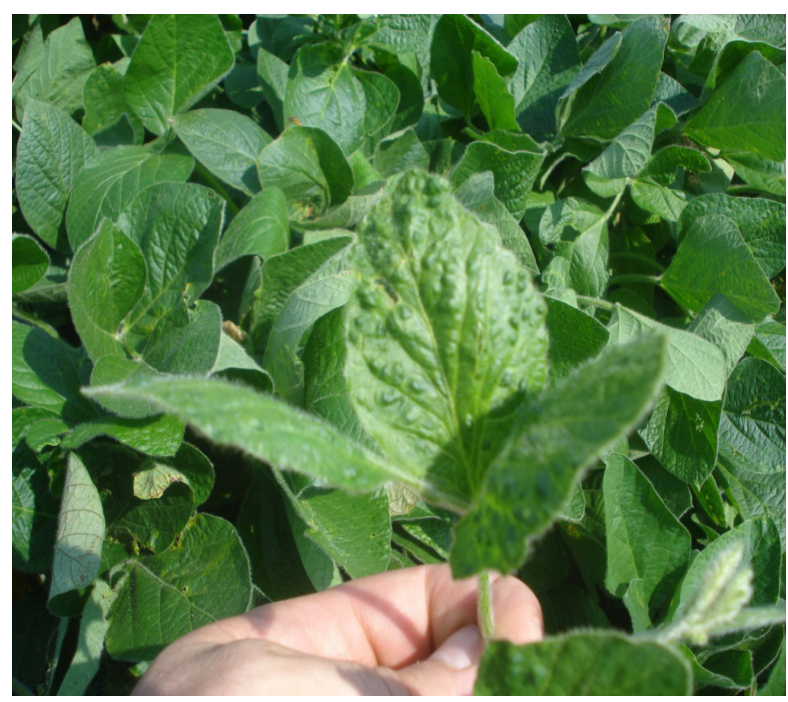

Fig. 1. (left) Leaf symptoms (curl) of virus infection.

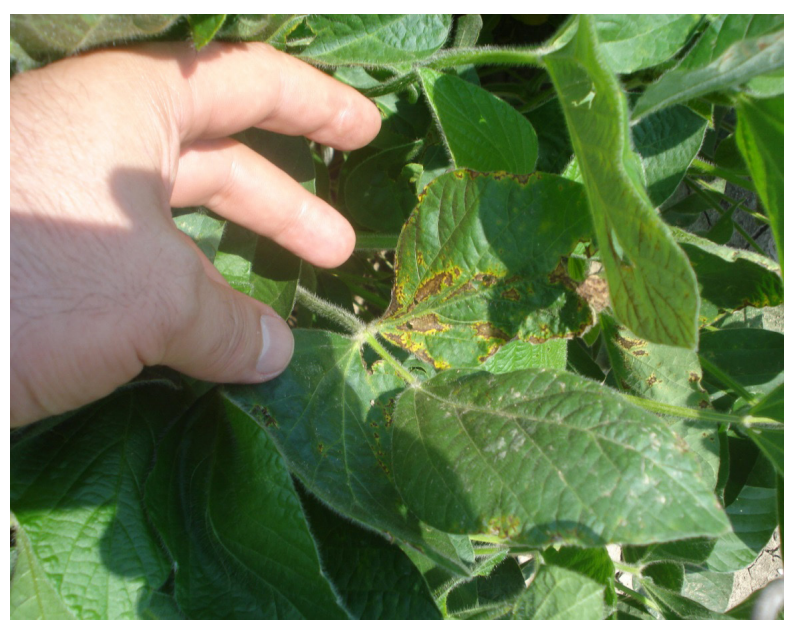

Fig. 2. (middle) Ragged appearance of foliage resulting from bacterial burning. 
plant, yellowing of the lower leaves, defoliation, marginal necrosis and death of the plant. On older plants, symptoms are more distinct between the blossoming and fruit maturation stages.

The data presented in Table 1 show the results on the behaviour of some soybeans cultivars to the diseases attack under natural contamination.

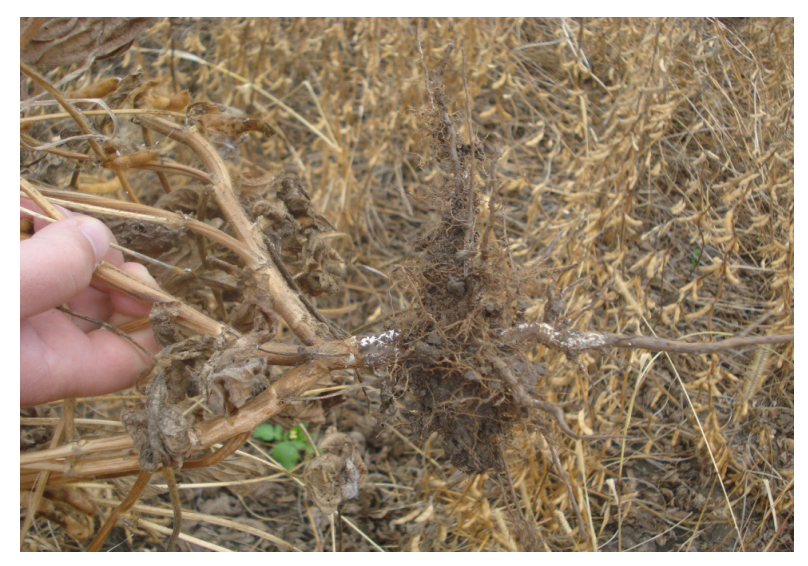

Fig. 3. (right) Fusarium sp. mycelium on soybean root.
Scouting in growth stage R1. It is noteworthy that there was no attack of Pseudomonas savastanoi pv. glycinea and Fusarium species in none of the three cultivars studied during years 2013 at first scouting in the two locations. At the same scouting stage cultivar PR91M10 showed the lowest attack degree $(0.05 \%)$ of Soybean mosaic potyvirus in Unirea city. Low values of the attack degree of Soybean mosaic potyvirus $(0.1 \%)$ presented the same cultivar in Great Island of Brăila.

PR92B63 cultivar showed at first scouting the highest attack degree of Soybean mosaic potyvirus $(0,2 \%$ in Unirea city and $0,3 \%$ in Great Island of Brăila).

Scouting at growth stage R4. In the second scouting stage frequency plants attacked by Soybean mosaic potyvirus ranged from 4\% (PR91M10 cultivar) to 8\% (PR92M22 cultivar), and the intensity of the attack ranged from 12.5\% (PR92B63 and PR92M22 cultivars) to 15.0\% (PR91M10 cultivar) in Unirea city, and

Tab. 1. Scouting the attack of mosaic (SMV) bacterial burn, and fusarium wilt on tested soybean cultivars investigated (Unirea city and Great Island, county of Brăila, 2013)

\begin{tabular}{|c|c|c|c|c|c|c|c|c|}
\hline \multirow{3}{*}{ Location } & \multirow{3}{*}{ Cultivars } & \multirow{3}{*}{ Pathogen } & \multicolumn{6}{|c|}{ Scoring growth stage } \\
\hline & & & \multicolumn{3}{|c|}{$\mathrm{R} 1$} & \multicolumn{3}{|c|}{$\mathrm{R} 4$} \\
\hline & & & $\mathrm{F}^{1}(\%)$ & $\mathrm{I}^{2}(\%)$ & $\mathrm{AD}^{3}(\%)$ & $\mathrm{F}(\%)$ & I (\%) & $\mathrm{AD}(\%)$ \\
\hline \multirow{9}{*}{ Unirea } & \multirow{3}{*}{ PR91M10 } & SMV & 1 & 5 & 0.05 & 4 & 15 & 0.6 \\
\hline & & PSG & 0 & 0 & 0 & 15 & 5 & 0.75 \\
\hline & & Fusarium sp. & 0 & 0 & 0 & 5 & 100 & 5.0 \\
\hline & \multirow{3}{*}{ PR92B63 } & SMV & 4 & 5 & 0.2 & 5 & 12.5 & 0.62 \\
\hline & & PSG & 0 & 0 & 0 & 5 & 5 & 0.25 \\
\hline & & Fusarium sp. & 0 & 0 & 0 & 1 & 100 & 1.0 \\
\hline & \multirow{3}{*}{ PR92M22 } & SMV & 2 & 5 & 0.1 & 8 & 12.5 & 1.0 \\
\hline & & PSG & 0 & 0 & 0 & 10 & 5 & 0.5 \\
\hline & & Fusarium sp. & 0 & 0 & 0 & 3 & 100 & 3.0 \\
\hline \multirow{9}{*}{$\begin{array}{l}\text { Great } \\
\text { Island }\end{array}$} & \multirow{3}{*}{ PR91M10 } & SMV & 2 & 5 & 0.1 & 5 & 10 & 0.5 \\
\hline & & PSG & 0 & 0 & 0 & 20 & 5 & 1.0 \\
\hline & & Fusarium sp. & 0 & 0 & 0 & 2 & 100 & 2.0 \\
\hline & \multirow{3}{*}{ PR92B63 } & SMV & 6 & 5 & 0.3 & 6 & 15 & 0.9 \\
\hline & & PSG & 0 & 0 & 0 & 4 & 5 & 0.2 \\
\hline & & Fusarium sp. & 0 & 0 & 0 & 4 & 100 & 4.0 \\
\hline & \multirow{3}{*}{ PR92M22 } & SMV & 2.5 & 5 & 0.12 & 5 & 15 & 0.75 \\
\hline & & PSG & 0 & 0 & 0 & 11 & 5 & 0.55 \\
\hline & & Fusarium sp. & 0 & 0 & 0 & 1 & 100 & 1.0 \\
\hline
\end{tabular}

${ }^{1} \mathrm{~F}(\%)=$ Frequency; ${ }^{2} \mathrm{I}(\%)=$ Intensity; ${ }^{3} \mathrm{AD}(\%)$ = Attack degree. 
in Great Island of Brăila frequency ranged from 5.0 to $6.0 \%$ and intensity ranged from 10.0 to $15.0 \%$. Frequency plants attacked by bacterial burning ranged from 5.0\% (PR92B63 cultivar) to $15.0 \%$ (PR91M10 cultivar) in Unirea city. PR91M10 cultivar showed the highest attack degree of bacterial burning (1.0\%) at this growth stage in Great Island of Brăila. The highest attack degree of Fusarium species (5.0\%) was recorded in PR91M10 cultivar, and the low values (1.0\%) had PR92B63 and PR92M22 cultivars.

\section{CONCLUSION}

Soybean mosaic potyvirus and bacterial burning in soybeans was limited to leaves. Soybean mosaic potyvirus is currently not a production problem in Brăila because disease levels are very low. Symptoms of bacterial burning occurred on the upper floor leaves. Plants attacked by Fusarium species were completely wilted and the attack was located in the hearths. In our opinion, all three cultivars had very good reaction against Soybean mosaic potyvirus, Pseudomonas savastanoi pv. glycinea, and Fusarium species attack.

Acknowledgements. The paper was published under de frame of European Social Found, Human Resources Development Operational programme 2007-2013, project no. POSDRU/159/1.5/S/132765.

\section{REFERENCES}

1. Dencescu S, Popa Gh (1973). Soiuri de soia cultivate și tehnologia producerii de semințe. Probleme agricole 4: 5-12.

2. Gross DC, Cody YS (1985). Mechanisms of plant pathogenesis byPseudomonas species. Canadian Journal of Microbiology 31(4): 403-410.

3. Domier LL, Hobbs HA, McCoppin NK, Bowen CR, Steinlage TA, Chang S, Wang Y, Hartman GL (2011). Multiple loci condition seed transmission of Soybean mosaic virus (SMV) and SMV-induced seed coat mottling in soybean. Phytopathology 101: 750-756.

4. Fehr WR, Caviness CE, Burmood DT, Pennington JS (1971). Stage of development descriptions for soybeans, Glycine max (L.) Merrill. Crop Science 11: 929-931.

5. Gardan L, Bollet C, Ghorrah Abu M, Grimont F, Grimont PAD (1992). DNA Relatedness among the pathovar strains of Pseudomonas syringae subsp. savastanoi Janse (1982) and proposal of Pseudomonas savastanoi sp. nov. Int. J. Syst. Bacteriol. 42 (4): 606-612.

6. Jagtap G, Dey U (2012). Bacterial Blight of Soybean: Pseudomonas syringae pv. glycinea. Lap Lambert Academic Publishing.

7. Janse JD (1982). Pseudomonas syringae subsp. savastanoi (ex Smith) subsp. nov., nom. rev., the bacterium causing excrescences on Oleaceae and Nerium oleander L. Int. J. Syst. Bacteriol. 32:166-169.

8. Sinclair JB, Backman PA (1989). Compendium of Soybean diseases, Third ed. The American Phytopathological Society.

9. Wang Y, Hobbs HA, Bowen CR, Bernard RL, Hill CB, Haudenshield JS, Domier LL, Hartman GL (2006). Evaluation of soybean cultivars, 'Williams' isogenic lines, and other selected soybean lines for resistance to two Soybean mosaic virus strains. Crop Sci. 46:2649-2653. 